\title{
Evaluation of the Reasons for Emergency Department Application in Patients with Peritoneal Dialysis
}

\section{Periton Diyalizli Hastalarda Acil Servis Başvurusu Nedenlerinin Değerlendirilmesi}

\section{Sümeyra Koyuncu', @Cihan Uysal', ๑Ali Gündoğdu', @ismail Koçyiğit', Murat Hayri Sipahioğlu', @Oktay Oymak', @Bülent Tokgöz'}

'Erciyes University School of Medicine, Department of Internal Medicine, Division of Nephrology, Kayseri, Turkey

\begin{abstract}
Aim: Severe acute problems, which are related to different systems, could be reasons for applying to the emergency department in patients with peritoneal dialysis. In this study, the aim was to evaluate the reasons and treatment of applications to the emergency department in these patients after office hours.

Material and Method: This study included followed up CAPD patients, who applied to the Emergency Department between January 2017 and May 2020 at our University. Demographical, biochemical, and clinical data, such as, renal, peritoneal, and weekly $\mathrm{Kt} / \mathrm{V}$, normalized protein catabolic rate $(\mathrm{nPCR})$, peritoneal UF, and GFR were recorded from the outpatient's department data. In addition, reasons for application to emergency services and hospitalization were evaluated.

Results: 38 peritoneal dialysis patients applied 88 times to the emergency department and were hospitalized between 2017 and 2020. Patients, who applied after office hours were included in the study. Around 130 patients were regularly followed-up in our CAPD outpatient clinic during this period. While the most important peritoneal reasons for admission were exit site infection and catheter dysfunction, extra peritoneal complications were various. Patients were hospitalized in the Cardiology and General Surgery departments with a high rate of acute cardiovascular events and acute abdominal pathologies.

Conclusion: Although the first approach to these patients in the emergency department is usually performed by a consulted nephrologist, effective and priority treatment could only be given by an emergency doctor, who has knowledge about the special problems of dialysis patients.
\end{abstract}

Keywords: Peritoneal dialysis, emergency, hemodyalisis
Öz

Amaç: Periton diyalizi olan hastalarda farklı sistemlere bağlı ciddi akut problemler acil servise başvuru nedeni olabilir. Bu çalışmada bu hastalarda mesai saatleri dışında acil servise başvuru nedenleri ve tedavilerinin değerlendirilmesi amaçlanmıştır.

Gereç ve Yöntem: Bu çalışmaya Üniversitemizde Ocak 2017-Mayıs 2020 tarihleri arasında Acil Servise başvuran takipteki SAPD hastaları dahil edildi. Renal, peritoneal ve haftalık Kt/N, normalize protein katabolik hızı (nPCR), peritoneal UF ve GFR gibi demografik, biyokimyasal ve klinik veriler poliklinik verilerinden kaydedildi. Ayrıca acil servise başvuru ve hastaneye yatış nedenleri değerlendirildi.

Bulgular: 2017-2020 yılları arasında 88 kez acil servise başvuran 38 periton diyalizi hastası hastaneye yatırıldı. Çalışmaya mesai saatleri dışında başvuran hastalar dahil edildi. Bu süre içinde SAPD polikliniğimizde yaklaşık 130 hasta düzenli olarak takip edildi. En önemli peritoneal yatış nedenleri çıkış yeri enfeksiyonu ve kateter disfonksiyonu iken, ekstra peritoneal komplikasyonlar çeşitliydi. Hastalar yüksek oranda akut kardiyovasküler olay ve akut karın patolojileri ile Kardiyoloji ve Genel Cerrahi bölümlerine yatırıldı.

Sonuç: Bu hastalara acil serviste ilk yaklaşım genellikle konsülte edilen bir nefrolog tarafından yapılsa da etkili ve öncelikli tedavi ancak diyaliz hastalarının özel sorunları hakkında bilgi sahibi bir acil servis doktoru tarafından verilebilir.

Anahtar Kelimeler: Periton diyalizi, acil servis, hemodiyaliz

Corresponding (iletişim): Sumeyra Koyuncu, Erciyes University School of Medicine, Department of Internal Medicine, Division of Nephrology, Kayseri, Turkey

E-mail (E-posta): sumeyraozberk@hotmail.com

Received (Geliş Tarihi): 28.12.2021 Accepted (Kabul Tarihi): 07.01 .2022 


\section{INTRODUCTION}

Peritoneal dialysis (PD) has been used to treat acute kidney failure (ARF) in humans since 1923. It is one of the effective treatment strategies, which has been used in both acute and chronic renal disease, using the persons own peritoneal membrane without the need of expensive machinery and equipment. Acute complications of PD are common and management could be easier if recognized early. ${ }^{[1-3]}$ Mechanical complications, peritonitis, pleural effusion, volume changes, and electrolyte imbalance are common complications in patients, who were admitted to the emergency department. In addition, it was reported that cardiac complications and problems associated with acute abdomen are also common in this patient group. ${ }^{[3]}$ The mechanical complications may be related to insufficient drainage and leakage. Leakage at the exit site of the catheter may require surgical consultation. Arising from catheter or exit-site leakage may also require surgical evaluation. Peritonitis is the most common infectious problem. It is the most common reason for hospitalization in the continuous ambulatory peritoneal dialysis (CAPD) group, who were admitted to the emergency department. ${ }^{[4,5]}$ Exitsite infection is one of the infectious complications, which usually occurs with exudative drainage with erythema, and irritation. ${ }^{[6]}$

Patients are also admitted to emergency departments because of "surgical" peritonitis due to other intra-abdominal pathologies but most of them are initially treated as PDassociated peritonitis. However, clinicians should be alerted to the possibility of peritoneal emergency with a lack of response to the standard approaches and when there is presence of enteric organisms particularly E. coli. Diagnosis can be difficult in these patients and early surgical referral and appropriate surgical approach (laparotomy rather than simple catheter removal) should be performed immediately to reduce morbidity and mortality. ${ }^{[7,8]}$ Hernias are common problems among other abdominal complications, which were reported in 10 to $25 \%$ of CAPD patients. When a hernia is incarcerated, patients can present with pain and vomiting, which is a result of intestinal obstruction. ${ }^{[9]}$ As known, cardiovascular problems are the most common cause of death in the dialysis population. The need of emergency cardiac care, which is provided by emergency physicians, will be increased as the dialysis population ages. Coronary artery disease, angina, and arrhythmias, especially are among the reasons for applying to the emergency department of these peritoneal dialysis patients. In addition, many acute problems, which are related to different systems, could be reasons for applying to the emergency department by peritoneal dialysis patients. ${ }^{[10,11]}$

In this study, we aimed to evaluate the application reasons, treatment, and complications of peritoneal dialysis patients in the emergency department after office hours.

\section{MATERIAL AND METHOD}

After obtaining ethics committee approval from the Medical School (no: 2020/618), consent was obtained from all participants. All procedures were carried out in accordance with the ethical rules and the principles of the Declaration of Helsinki.

This study included CAPD follow up patients, who applied to the Emergency Department between January 2017 and May 2020. Hemoglobin (Hb), leukocyte, blood urea nitrogen, creatinine $(\mathrm{Cr})$, uric acid, calcium $(\mathrm{Ca})$, phosphorus $(\mathrm{P})$, alkaline phosphatase, albumin, C-reactive protein (CRP) levels, and medication history were obtained from the patient records. In our study, all patients were on a standard PD treatment schedule (4 or 5 times a day, 2000- or 2500-mL volume change). Demographic and clinical data, such as 4-hour peritoneal equalization test (D/P Cr), renal, peritoneal, and weekly Kt $/ \mathrm{V}$, normalized protein catabolic rate (nPCR), and peritoneal UF and GFR were recorded from the outpatient's department data. In addition, reasons of application to emergency services and hospitalization were evaluated.

\section{Statistical Analysis}

The SPSS 15.0 package(Statistical Packages for Social Sciences; SPSS Inc. Chicago, Illinois, USA) was used to analyze the data. The data that could be measured and provided parametric conditions were given as arithmetic mean \pm standard deviation $(\mathrm{x} \pm \mathrm{ss})$. the data that could be measured but did not provide parametric conditions were defined as median (25\% -75\%). Suitability of normal distribution was evaluated with the "Kolmogorov-Smirnov" test. One-way Anova (Tukey test) was used to evaluate the difference between groups. Kruskal- Wallis was performed for nonparametric data. Pearson correlation was used for correlation. A p value, which was $<0.05$ was considered significant.

\section{RESULTS}

The demographical and clinical data of the patients is summarized in Table 1. The mean age of the patients was $56.6 \pm 14.5$ and the duration of dialysis was $43 \pm 29.0$ months. 38 peritoneal dialysis patients applied 88 times to the emergency department and were hospitalized between 2017 and 2020. Only the patients who applied after office hours were included. It was observed that patients, who received peritoneal dialysis treatment, sometimes came to the hospital after office hours due to their living in villages and therefore applied to emergency services. Around 130 patients were regularly followed-up in our CAPD outpatient clinic during this period. The patients most frequently applied to the emergency department with complaints of abdominal pain, nausea-vomiting, and fever. 
Table 1. Clinical and demographical features of the patients

\begin{tabular}{lc} 
Parameters & Patients ( $\mathbf{n = 3 8 )}$ \\
\hline Age (year) & $56.6 \pm 14.5$ \\
Gender male (\%) & $22(57)$ \\
Cause of chronic renal failure & \\
$\quad$ Diabetes mellitus & 16 \\
$\quad$ Hypertension & 10 \\
$\quad$ Polycystic kidney disease & 3 \\
$\quad$ Pyelonephritis & 2 \\
$\quad$ Glomerulonephritis & 2 \\
$\quad$ Amiloidosis & 1 \\
$\quad$ Unknown & 4 \\
Duration of CAPD (month) & $43 \pm 29.0$ \\
Body mass index (kg/m²) & $25.3 \pm 3.41$ \\
WBC (mm ${ }^{3}$ ) & $8030 \pm 3092$ \\
Hemoglobin (g/dl) & $10.9 \pm 1.8$ \\
Albumin (g/dl) & $3.85 \pm 0.5$ \\
Residual urine volume (ml/day) & $930 \pm 510$ \\
Kt/V & $2.21 \pm 0.84$ \\
D/P Creatinine & $0.70 \pm 0.08$ \\
\hline CAPD: Continuous Ambulatory Peritoneal Dialysis, WBC: White Blood Cell, Kt/N: Urea Clearance \\
Normalized To Total Body Water, D/P Creatinine:Urine Creatinine To Serum Creatinine
\end{tabular}

The most common causes of primary renal failure of the patients were diabetes mellitus and hypertension. The PDrelated complications of the patients are summarized in Table 2. The most important reasons for admission were peritoneal, exit site infection, and catheter dysfunction followed by extra peritoneal complications, which were rarer. The most common factors of patients hospitalized for peritonitis are summarized in Table 3. The most common cause was S. epidermidis, a gram-positive bacterium. Patients hospitalized in several departments for peritoneal or extra peritoneal reasons are summarized in Table 4.

\begin{tabular}{lc} 
Table 2. Reasons for admission to the Nephrology clinic from Emergency \\
department & N \\
Reasons & 26 \\
\hline Peritonitis & 5 \\
Exit site infection & 4 \\
Hypervolemia & 5 \\
Kateter Dysfunction & 2 \\
Uremic Symptoms & 2 \\
Leakage & 1 \\
EPS & 1 \\
Hydrotorax &
\end{tabular}

Mainly, the patients were hospitalized in the Cardiology and General Surgery departments with a high rate of acute cardiovascular events and acute abdominal pathologies. In addition, intracranial pathologies were also frequently seen. During the follow-up of these patients, one died in the Neurosurgery intensive care unit (ICU), 4 patients died in the Internal medicine ICU, 4 died in the Cardiology department and 2 died in the Nephrology department.
Table 3. Causative organisms grown in peritoneal fluid culture.

\begin{tabular}{lc}
\hline Microorganism & $\mathbf{n}(\%)$ \\
\hline Gram-positive & \\
S. epidermidis & $6(23 \%)$ \\
MSSA & $4(15 \%)$ \\
MRSA & $3(11 \%)$ \\
CNS & $1(3 \%)$ \\
Enterococcus & $1(3 \%)$ \\
Gram-Negative & \\
E. coli & $3(11 \%)$ \\
Pseudomonas & $1(3 \%)$ \\
Culture-negative & $7(26 \%)$ \\
\hline $\begin{array}{l}\text { MRSA: Methicillin resistance in Staphylococcus aureus, MSSA: Methiillin-susceptible S. aureus } \\
\text { CNSA:Coagulase-negative Staphylococcus }\end{array}$
\end{tabular}

Table 4. Reasons for hospitalization into the other clinics from Emergency Department

\begin{tabular}{|c|c|c|}
\hline $\begin{array}{l}\text { Admission } \\
\text { Numbers }\end{array}$ & Hospitalization & Diagnosis \\
\hline \multirow{2}{*}{2} & \multirow{2}{*}{$\begin{array}{l}\text { Obstetric and } \\
\text { gynecology }\end{array}$} & Ovarian cyst rupture \\
\hline & & Ectopic Pregnancy \\
\hline \multirow{3}{*}{3} & \multirow{3}{*}{ Neurosurgery } & Subarachnoid hemorrhage \\
\hline & & Intracranial hemorrhage \\
\hline & & Cerebral travma \\
\hline \multirow{4}{*}{2} & \multirow{2}{*}{ Orthopedic surgery } & Diabetic Foot \\
\hline & & Hip/femur fracture \\
\hline & \multirow{6}{*}{ General Surgery } & İleus (3) \\
\hline & & $\begin{array}{l}\text { Acute incarcerated inguinal } \\
\text { hernia }\end{array}$ \\
\hline \multirow[t]{4}{*}{8} & & Volvulus \\
\hline & & Acute cholecystitis \\
\hline & & Intraabdominal abscess \\
\hline & & Acute pancreatitis \\
\hline 2 & $\begin{array}{l}\text { Gastroenterology / } \\
\text { Hepatology }\end{array}$ & Upper gastrointestinal bleeding \\
\hline \multirow{2}{*}{2} & \multirow{2}{*}{ Endocrinology } & Diabetic ketoacidosis \\
\hline & & Hypoglycemia \\
\hline 1 & Dermatology & Anaphylaxis \\
\hline 1 & $\begin{array}{l}\text { Ear, Nose and Throat } \\
\text { Disorders }\end{array}$ & Pharyngeal Abscess \\
\hline \multirow{5}{*}{12} & \multirow{5}{*}{ Cardiology } & $\begin{array}{l}\text { Myocardial infarction/ Angina } \\
\text { pectoris (6) }\end{array}$ \\
\hline & & Cardiac Failure (3) \\
\hline & & Arrhythmia \\
\hline & & Pericarditis \\
\hline & & Warfarin Overdose \\
\hline \multirow{2}{*}{4} & \multirow{2}{*}{ Infections Diseases } & Peritonitis (3) \\
\hline & & Covid 19 infection \\
\hline 1 & $\begin{array}{l}\text { Intensive Care (Internal } \\
\text { Medicine) }\end{array}$ & Sepsis \\
\hline 2 & Neurology & Cerebrovascular disease \\
\hline 2 & $\begin{array}{l}\text { Intensive Care } \\
\text { (Neurosurgery) }\end{array}$ & Loss of consciousness \\
\hline
\end{tabular}




\section{DISCUSSION}

The number of patients, who underwent hemodialysis and peritoneal dialysis, has increased worldwide. Cardiovascular disease and infections are among the leading causes of death in this patient group. In addition, bleeding, cardiac tamponade, electrolyte imbalance, pericardial tamponade, and acute abdomen are other important causes of mortality. [12]

In our study, the most common causes of emergency department applications were cardiac and acute abdomen related problems and the most common causes of deaths were relevant to these complications. This is similar to the cases of admission to the emergency department in our country. The high incidence of hypertension and diabetes in the dialysis population may be responsible for the increased risk for myocardial infarction. In addition to atherosclerosis, anemia and heart failure related to low cardiac output could reduce the myocardial oxygen supply. Left ventricular hypertrophy, volume overload, and hypertension caused increased left ventricular wall stress and increased myocardial oxygen request. ${ }^{[12,13]}$ Arrhythmia prevention, relief from pain and anxiety, and treatment of heart failure should be performed for dialysis patients with myocardial infarction or unstable angina in the emergency department. Diagnosis of unstable angina and infarction in dialysis patients could be difficult to understand, so hospitalization may be required in both cases. The cause of death in patients with myocardial infarction was mostly cardiac arrhythmias. Serum especially with electrolyte imbalances was common causes of arrhythmias in these patients. Arrhythmia due to hypotension and acute volume changes can often happen in patients with atherosclerotic heart disease during dialysis break. Arrhythmias are also common in severe anemia, left ventricular hypertrophy, and digitalis usage. ${ }^{[14]}$ Acute heart failure in dialysis patients is often caused by increased salt in the diet or excessive loading of intravenous fluids. ${ }^{[15,16]}$ Basic treatment principles consist of supportive oxygen, preload reduction, and ultrafiltration. It is necessary to identify the cause of acute decompensation and reverse it. For reducing cardiac preload, furosemide has efficiency as diuresis. ${ }^{[12]}$ Pericarditis occurs at any time especially in $40 \%$ of cases within 3 months of starting dialysis and has been seen in $2 \%$ to $19 \%$ of long-term dialysis treatments and could cause fatal complications. Fatal complications develop at any time in long-term dialysis patients, but $40 \%$ of cases occur within 3 months of starting dialysis. ${ }^{[17-20]}$

Although humoral and cellular immunity may be altered in dialysis patients, it was clear that the main reason for the increased incidence of infection was exposure to pathogens in the blood and peritoneal access sites. Clinicians should consider peritonitis a possibility when blurred dialysate occurs. Symptoms such as fever and abdominal pain, nausea, vomiting and diarrhea generally are seen together. Empirical treatment should be initiated in these patients immediately after taking the necessary samples. ${ }^{[5,21]}$ However, patients with renal failure could have more than one medical problem at the same time because their immune system is suppressed. Even a simple PD catheter replacement could cause surgical peritonitis, which cannot be treated. Delays in diagnosis and treatment for surgical peritonitis inevitably lead to increased morbidity and mortality. Early diagnosis and referral to a surgeon with sufficient experience would reduce the mortality in these patients. Clear peritoneal fluid with pain that is out of proportion to the abdominal examination findings should be considered as a possible incarcerated hernia. [22] Acute pleural effusion is a rare complication and usually occurs in early treatment periods. In one study, the most common PD complication was over hydration. If the patient is gaining weight, central venous pressure is rising, or the recovered waste is not at least $90 \%$ of the infused dialysate, the treatment should be changed to ultrafiltration with higher dextrose $(2.5 \%$ or $4.25 \%)$ solutions. Acute hydrothorax is a rare complication of PD and has been reported in only $1.6 \%$ of 3,195 CAPD patients in a series. The majority (88\%) was rightsided effusions and was associated with dyspnea. ${ }^{[3,23]}$

In our study, we evaluated PD patients, who applied to the emergency department, with several different symptoms and were hospitalized in various clinical departments. Although complications were predominantly related to peritoneal dialysis, cardiovascular problems and acute abdominal surgery were also prominent. However, it should be kept in mind that these patients could present with other acute problems independent of the underlying renal failure and the diagnosis could be harder than with renal failure itself. Since patient complaints include a wide variety of clinics from simple dyspepsia to acute abdomen, the emergency department physician has a great responsibility.

\section{CONCLUSION}

We think that several problems of patients with renal failure could be delayed by referral to a nephrologist. Furthermore, emergency doctors should be prepared to recognize and treat life-threatening problems during this period. Even though cardiovascular problems, infection, and electrolyte abnormalities are more common, recognizing other pathologies, which require acute surgical intervention, may help reduce mortality.

\section{ETHICAL DECLARATIONS}

Ethics Committee Approval: After obtaining ethics committee approval from the Medical School (no: 2020/618), consent was obtained from all participants.

Informed Consent: Because the study was designed retrospectively, no written informed consent form was obtained from patients.

Referee Evaluation Process: Externally peer-reviewed. 
Conflict of Interest Statement: The authors have no conflicts of interest to declare.

Financial Disclosure: The authors declared that this study has received no financial support.

Author Contributions: All of the authors declare that they have all participated in the design, execution, and analysis of the paper, and that they have approved the final version.

\section{REFERENCES}

1. Mehrotra R, Devuyst O, Davies SJ, Johnson DW. The Current State of Peritoneal Dialysis. J Am Soc Nephrol 2016;27(11):3238-52.

2. Avendano MBI, Solorzano GY, Valenzuela JR, et al. Automated peritoneal dialysis as a lifesaving therapy in an emergency room:Report of four cases. Kidney Int 2008;73(S108):S173-S6.

3. Labato MA. Peritoneal dialysis in emergency and critical care medicine. Clin Tech Small Anim Pract 2000;15(3):126-35

4. Wolfson $A B$. End-stage renal disease:emergencies related to dialysis and transplantation. In:Wolfson AB, Harwood-Nuss A, eds. Renal and urologic emergencies. New York:Churchill Livingstone;1986:23-50.

5. Alkan Çeviker S, Günal Ö, Kılıç SS, Demirağ MD. Sürekli Ayaktan Periton Diyalizi Hastalarında Gelişen Peritonitlerin Epidemiyolojik ve Mikrobiyolojik Özelliklerinin Analizi. Mustafa Kemal Üniversitesi Tıp Derg 2019;41-5.

6. Holley JL, Foulks $\mathrm{CJ}$, Moss $\mathrm{AH}$, et al. Ultrasound as a tool in the diagnosis of exit-site infections in patients undergoing continuous ambulatory peritoneal dialysis. Am J Kidney Dis 1989;14:211-6.

7. Tzamaloukas AH, Obermiller LE, Gibel LJ et al. Peritonitis associated with intra-abdominal pathology in continuous ambulatory peritoneal dialysis patients. Perit Dial Int 1993;13:335-7.

8. Wellington JL, Rody K. Acute abdominal emergencies in patients on longterm ambulatory peritoneal dialysis. Can J Surg 1993;36:522-4

9. Maher JF, Maher AT. Continuous ambulatory peritoneal dialysis. Am Fam Physician 1989;40:187-92

10. Wina AJ, Brunner FP, Brvnaer H, et al. Cardiovascularrelated ca;ses'of death and the iat:of patients with renovascular disease. Contrib Nephrol 1984;41:306-11

11. Ritz E, Wiecek A, Gnasso A, Augustin J. Is Atherogenesis Accelerated in Uremia Contrib Nephrol 1986;52:1-9

12. Clifford C. Cloonan, Cloyd B. Gatrell, Howard M. Cushner, Emergencies in continuous dialysis patients: Diagnosis and management. Am J Emerg Med 1990; 8(2):134-48.

13. Eray, Oktay. "Türkiye'de acil servise başvuran hastaların profilleri." Kardiyovasküler Akademi Derneği. ebülten:Ekim sayısı. Web sitesi:http:// cardiovascularacademy. com/KPDData/userfiles/file/OktayBulten14. pdf (2014).

14. Şahpaz, Fatih. "Periton Diyalizi Hastalarında Homosistein Düzeylerindeki Artışın Ateroskleroza Etkisi." J Clin Exp Invest 2016;7:47-51.

15. Nesheiwat Z, Lee JJ. Uremic Pericarditis 2021 Jul 26. In:StatPearls [Internet]. Treasure Island (FL):StatPearls Publishing;2021

16. Chugh S, Singh J, Kichloo A, Gupta S, Katchi T, Solanki S. Uremic- and Dialysis-Associated Pericarditis. Cardiol Rev 2021;29(6):310-3.

17. Comty CM, Wathen RL, Shapiro FL. Uremic pericarditis. Cardiovasc Clin 1976;7:219-35

18. Marini PV, Hull AR. Uremic pericarditis:A review of fncidence and management. Kidney Int 1975;7:163-6

19. Mitchell AG. Pericarditis during chronic haemodialysis therapy. Postgrad Med J 1974;50:741-5

20. Comty CM, and Shapiro FL. Cardiac complications, In Drukker W, et al (eds):Replacement of Renal Function by Dialysis (ed 2). Boston, MA, Martinus Nijhoff, 1986, p 605

21. Vas SI, Low DE, Oreopoulos DG. Peritonitis In Drukker W. et al (eds):Reolacement of Renal Function bv Dialvsis led 2). Boston,'MA,'Marbnus Nijhoff, 1981, p 344
22. Steiner RW, Halasz NA. Abdominal catastrophes and other unusual events in continuous ambulatory peritoneal dialysis patients. Am J Kidney Dis 1990;15:1-7.

23. Nomoto $Y$, Suga $T$, Nakajima $K$, et al. Acute hydrothorax in CAPD-a collaborative study of 161 centers. Am J Nephrol 1989;9:363-7. 